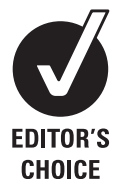

General practitioner, The Medical Center, Ashdod, Israel ${ }^{2}$ IDF Medical Corps, Israel

Correspondence to Dr Anthony S Oberman, 2/5 David Elazer Street, Raanana 43205, Israel,

anthonyo@doctors.org.uk

Received 6 April 2010

Revised 6 July 2010

Accepted 26 July 2010

Published Online First

28 October 2010

\title{
Medicine and the Holocaust: a visit to the Nazi death camps as a means of teaching medical ethics in the Israel Defense Forces Medical Corps
}

\author{
Anthony S Oberman, ${ }^{1,2}$ Tal Brosh-Nissimov, ${ }^{2}$ Nachman Ash ${ }^{2}$
}

\begin{abstract}
A novel method of teaching military medical ethics, medical ethics and military ethics in the Israel Defense Force (IDF) Medical Corps, essential topics for all military medical personnel, is discussed. Very little time is devoted to medical ethics in medical curricula, and even less to military medical ethics. Ninety-five per cent of American students in eight medical schools had less than $1 \mathrm{~h}$ of military medical ethics teaching and few knew the basic tenets of the Geneva Convention. Medical ethics differs from military medical ethics: the former deals with the relationship between medical professional and patient, while in the latter military physicians have to balance between military necessity and their traditional priorities to their patients. The underlying principles, however, are the same in both: the right to life, autonomy, dignity and utility. The IDF maintains high moral and ethical standards. This stems from the preciousness of human life in Jewish history, tradition and religious law. Emphasis is placed on these qualities within the Israeli education system; the IDF teaches and enforces moral and ethical standards in all of its training programmes and units. One such programme is 'Witnesses in Uniform' in which the IDF takes groups of officers to visit Holocaust memorial sites and Nazi death camps. During these visits daily discussions touch on intricate medical and military ethical issues, and contemporary ethical dilemmas relevant to IDF officers during active missions.
\end{abstract}

\section{INTRODUCTION}

A novel method of teaching military medical ethics, medical ethics and military ethics in the Israel Defense Force (IDF) Medical Corps, essential topics for all military medical personnel, is discussed.

Very little time is devoted to medical ethics in medical curricula, and even less to military medical ethics. Ninety-five per cent of American students in eight medical schools had less than $1 \mathrm{~h}$ of military medical ethics teaching and few knew the basic tenets of the Geneva Convention. ${ }^{1}$ Medical ethics differs from military medical ethics: the former deals with the relationship between medical professional and patient, while in the latter military physicians have to find a balance between military necessity and their traditional priorities to their patients. ${ }^{2}$ The underlying principles, however, are the same in both: the right to life, autonomy, dignity and utility. ${ }^{3}$

The IDF maintains high moral and ethical standards. This stems from the preciousness of human life in Jewish history, tradition and religious law.
Emphasis is placed on these qualities within the Israeli education system; the IDF teaches and enforces moral and ethical standards in all its training programmes and units. One such programme is 'Witnesses in Uniform' in which the IDF takes groups of officers to visit Holocaust memorial sites and Nazi death camps. During these visits daily discussions touch on intricate medical and military ethical issues, and contemporary ethical dilemmas relevant to IDF officers during active missions.

Extreme conditions and unprecedented mortality and morbidity inflicted by the Nazis during the Holocaust have created many dilemmas concerning medical and military medical ethics, although some say that the conditions were so extreme that little can be learnt. Many authors have suggested that medical ethics can be learnt from the Holocaust years, as the medical profession of the Third Reich, including medical and research institutes, played a central role in the development of the Holocaust and the implementation of the Final Solution. ${ }^{4}$ It shows how power was abused and how 'ordinary' good people can become engaged in evil experiments, mass murder and genocide. ${ }^{4}$ Nazi medicine represented a low water mark in medical ethics, ${ }^{5}$ although some people remained professional and compassionate. Dilemmas about individual versus public welfare, medical resource rationing, and clinical trials involving human subjects from this period can be examined.

The World Medical Association ${ }^{6}$ states that 'medical ethics in times of armed conflict is identical to medical ethics in times of peace'. Pellegrino states: 'There is no special medical ethics for active duty military physicians except in the most extreme conditions. ${ }^{2}$ Gross feels that medical ethics in war are not identical to medical ethics in times of peace and he argues that the demands of war require military physicians to embrace new moral priorities and responsibilities. ${ }^{3}$ Some feel that his views may have swung too far in the opposite direction. Rosner states that medical ethics at times of war are fundamentally different from those at times of peace, but concludes that when physicians are faced with a conflict between following state or national policies or following international principles of humanitarian law and medical ethics they should opt for the latter. ${ }^{7}$ We feel that medical ethics are similar in peace and war, thus lessons for both peace-time and war-time ethics can be learnt from the Holocaust years.

The opportunity to take medical officers on a physical and spiritual journey to Holocaust sites was used as a means to teach and discuss medical 
ethics. We describe the first of such journeys and evaluate its effect on the participants.

\section{METHODS}

A group of IDF commanders travelled to the Nazi death camps in Poland in July 2009 under the auspices of the IDF Medical Corps led by the Surgeon General. The group consisted of middle-ranking officers, and senior NCOs of the Medical Corps, including physicians, dentists, nurses, medics, psychiatrists, epidemiologists and administrative staff of the Corps. The visit was preceded by 3 days of extensive training in the Yad Vashem Holocaust Center (YVHC) and Museum in Jerusalem. Teaching comprised frontal lectures and audio-visual presentations (AVP) on general and medical-associated Holocaust topics. Personal witnesses related their Holocaust experiences in Israel and later in Poland. Officers participating were assigned projects to on work on during the trip.

In Poland, visits were made to concentration camps as well as other Holocaust sites and sites of pre-war Jewish interest. Memorial ceremonies were performed and homage was paid to Holocaust victims (figure 1) and to Jewish medical personnel of the time, especially those that perished during the Holocaust. Each day the group considered issues raised and their relevance to the current dilemmas of the medical officer during his daily work and missions.

Ethics can be taught in the classroom. ${ }^{8}$ However, there are many compelling advantages of and reasons for teaching at actual historical sites: visits to authentic sites create special learning experiences different from the classroom and they can raise the status of the subject by providing a unique atmosphere that may create a special desire to learn and stimulate further studies. This is especially relevant in the IDF, as many of its members have personal family connections and memories of the sites visited.

We describe some of the topics covered on the journey, including ethical dilemmas and important lessons for healthcare personnel.

\section{Ethical dilemmas regarding allocation of medical resources Allocation of insulin in the ghetto}

In the ghettos, all medications were confiscated by the Nazis, although Jews manufactured certain basic medications. ${ }^{9}$ The
Nazis allowed the Jews to buy back small quantities of standard medications at inflated prices. More advanced or expensive medications were not available to the Jews. Insulin was in short supply in the ghettos. In one ghetto, a Jewish doctor requested a meeting to decide whether the available insulin should be shared evenly so that nobody got enough or be given to a few selected patients. Present at the meeting were two doctors, a judge and a member of the Judenrat (Jewish Ghetto Council) who refused to decide and accused the doctor of being a Nazi collaborator. The doctor decided to allocate it to a few people (the less ill) but in the end insulin supplies ran out and all the patients perished.

During the Holocaust years there were severe shortages of supplies. Generally, when considering cases of severe shortage, the principle of Hume is applicable. Hume in 'The Circumstances of Justice' argued that in gross scarcity, where there is so little that survival is in doubt, no one person can be criticised for taking and holding on to what they have. In the case of the Holocaust, doctors allocated the scarce medical resources and ethical decisions were made by medical personnel. This type of allocation is discussed in the literature; for example in the first years of insulin availability Banting decided himself which terminally ill patients would receive insulin. Similarly, the Seattle Artificial Kidney Center Committee had to choose "who shall live'. As it had to be decided in these cases who would live and who would die, these were also cases of severe scarcity.

\section{The clandestine medical school in the Warsaw ghetto}

After entering Poland, the Nazis stopped all education in Poland. They aimed to produce a semi-literate Polish population, sufficient for being manual labourers. The last Jewish school closed on 4 December 1939. Later, the Nazis, allowed the Judenrat to provide some elementary and vocational schooling in the ghetto. The Nazis allowed the opening of personal hygiene courses in the ghetto to prevent epidemics. Under this guise, a secret medical school was opened, and courses in antiepidemic techniques were used as a cover for medical courses. Fear of epidemics kept the Nazis away from the school itself, which was affiliated to the University of Warsaw. The clandestine school functioned from May 1941 until July 1942. As many
Figure 1 The group marching into Auschwitz-Birkenau death camp.

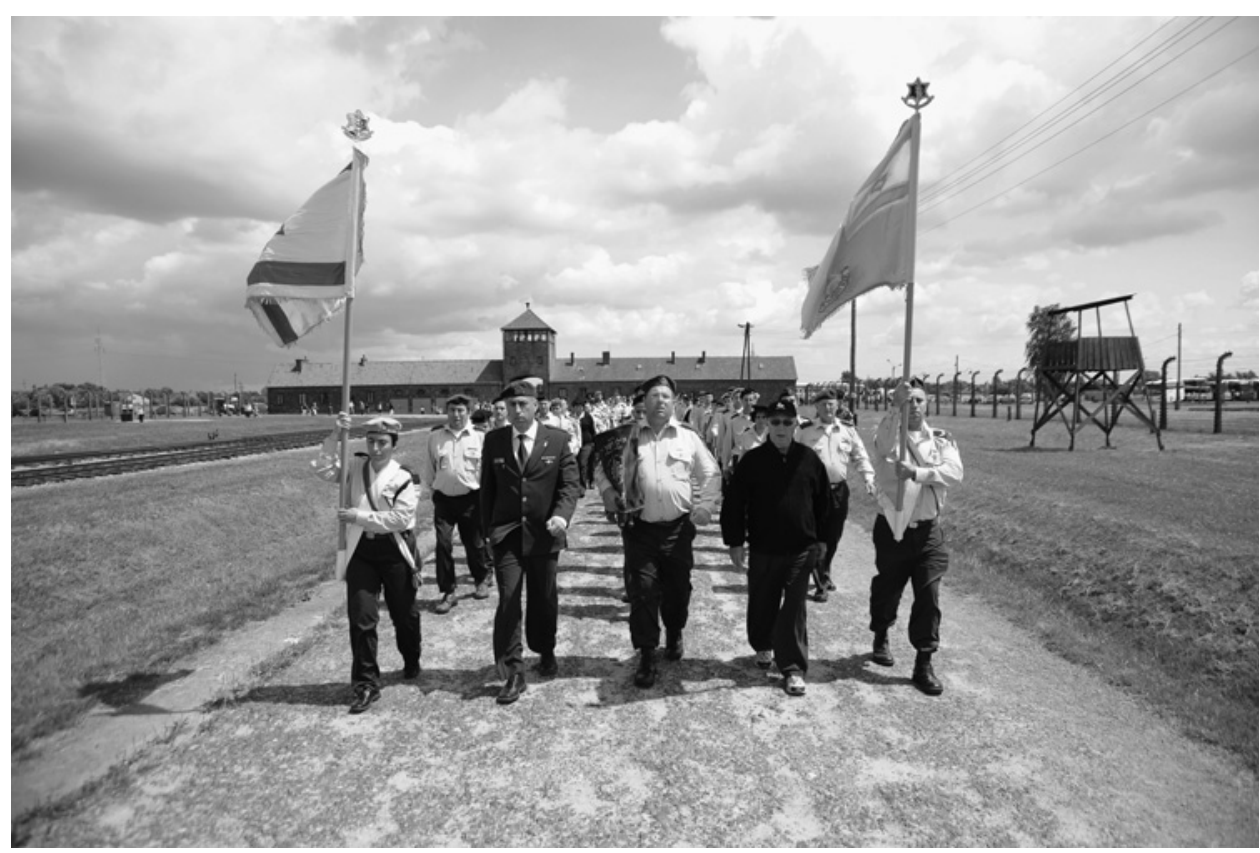


as 500 students studied in the school, but few survived the deportations to Treblinka extermination camp and it is estimated that only 50 students received certificates after the war. ${ }^{10}$

\section{Luba Bielicka Blum}

Luba Bielicka Blum studied and qualified at the nursing school in Warsaw, becoming its director at the outbreak of war. Blum obtained permission from the Nazis for the nursing school in the ghetto to continue to function. When the Nazis imposed mass deportations on the ghetto, including those of nurses, she had to make heart-rending decisions as to who would stay and who would go. She based her decisions on examination grades. Later, just before the ghetto uprising, Blum and her children, using her connections with Polish nurses, managed to escape from the Ghetto after the Nazis had killed the patients and most of her nurses at the hospital. ${ }^{11}$ Her story was related by the Surgeon General at her grave (figure 2).

Through these cases, we see how despite impossible conditions some medical practitioners continued with forbidden education, research and patient care, while facing hunger, disease and impending annihilation for themselves and their families. ${ }^{4}$

These cases illustrate principles of medical ethics as related to distributive justice and ethical triage $e^{3}$ and stimulated discussion of these principles.

\section{The medical oath and Nazi medical practice}

Traditionally, the Hippocratic Oath was sworn by the physician as the moral and ethical basis for his/her life's work. State licences allow the physician to practice medicine but the physician makes his oath voluntarily, to all humanity and not to any State. If State actions are not compatible with the oath, the physician must resist the demands of the State. ${ }^{12}$ In 1931 'Guidelines for New Therapy and Human experimentation', formulated by a Jewish German doctor and politician Dr Julius Moses, including 14 measures to prevent medical malpractice, was published in Germany. Under Nazi influence, the German medical profession willingly disregarded these principles, as well as the Hippocratic Oath, respecting instead the perceptions and priorities of the Third Reich. The Nazis even changed the terminology, replacing the idea of 'healthcare' with 'health leadership'-doctors no longer owing a duty to their patients as individuals but to the State. ${ }^{13}$ Legislation on human experimentation was rescinded. ${ }^{5}{ }^{14}$ Nazi doctors carried out forced sterilisations and implemented the Nuremberg laws medicalising Nazi social policies. ${ }^{5}$ They carried out a policy of euthanasia of the disabled and mentally ill and participated in mass exterminations and genocide, as well as sadistic experiments in the name of science.

One example was Dr Joseph Mengele and his inhuman method of containing spotted fever (typhus) and other infectious diseases in Auschwitz, as well as his infamous participation in selections. The group was told how one case of rubella in a certain inmate block led him to send 600 inmates of the 'infected' block and its adjacent blocks to their deaths in the gaschambers in order to contain the epidemic. ${ }^{15}$

The Nazi doctors medicalised killing by using controlled technology to kill a large number of people, as well as maintaining distance between killer and victim. This was important in enabling the Einsatzgruppen troops to carry out their ghastly work. ${ }^{16}$ Nazis disregarded the right to life, autonomy and dignity, as well as many other medical ethical principles. As far as military medical ethics were concerned, they showed gross disregard to non-combatants and prisoners, who were denied medical care, tortured and killed. The Nazis clearly showed moral complicity.

\section{Nazi pseudo-research and sadistic experiments}

Nazi pseudo-research and sadistic experiments were related to the group in the punishment block in Auschwitz, near Block 10 where many of these deeds took place. Hypothermic and hypobaric research that had taken place in Dachau, Germany, was described. Personal testimony was given by an officer whose grandmother had been repeatedly raped as part of a fertility and sterilisation pseudo-experiment at this very site.

One of the experimentation programmes that was studied at greater length was human hypothermic research in which Nazi physicians exploited concentration camp inmates. Their aim was to understand the consequences to German pilots downed over the North Sea, and how protection and medical treatment could be improved. The Nazis disregarded major principles of
Figure 2 Surgeon General, Israel Defense Force, relating Luba Blum's story at her grave.

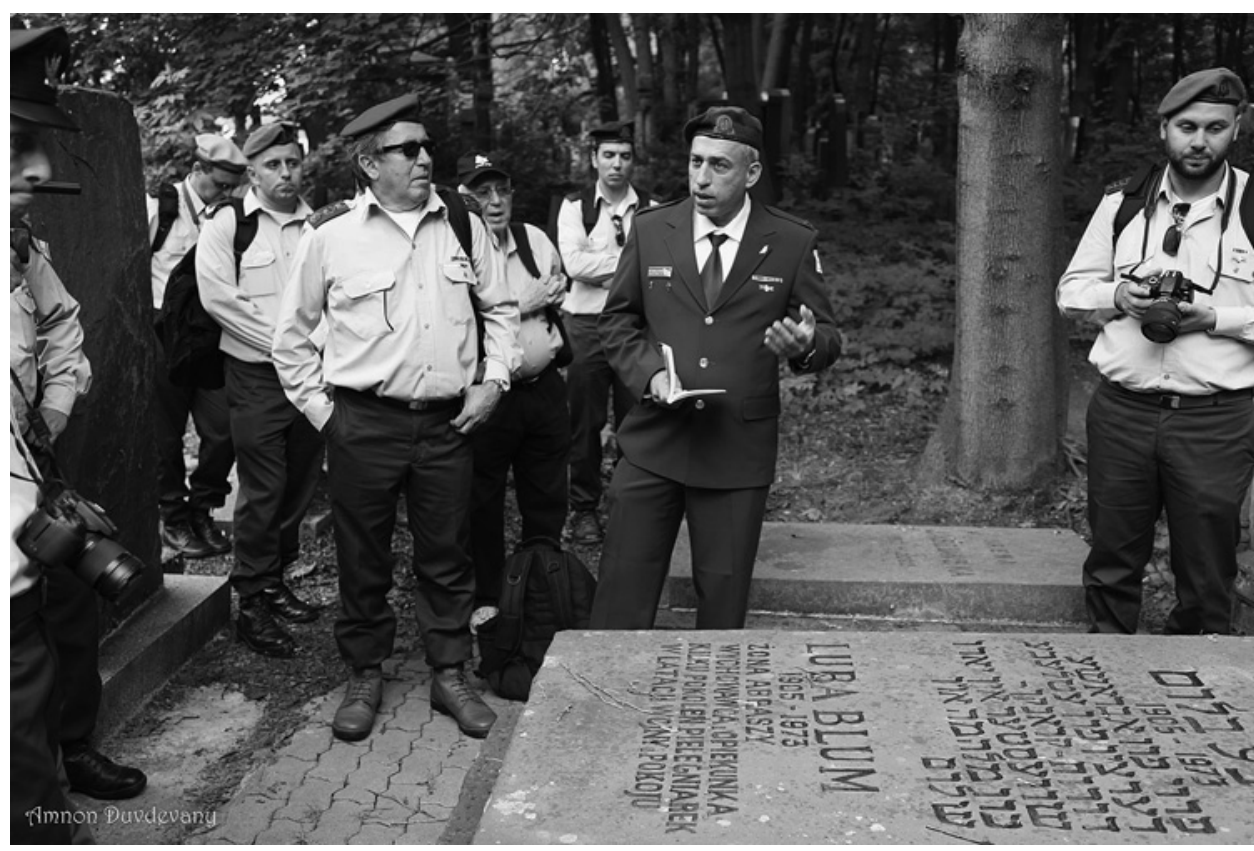


medical ethics, including voluntary and informed consent in human experimentation, as well as the right to life and dignity. Although many felt that the data were not of any real scientific value, others disagreed. Unfortunately and unethically, some used their findings after the war. The group discussed experimentation in general and human experimentation in particular. The discussion included guidelines for experimentation and the dilemmas in the rejection of unethical research. ${ }^{2}$

\section{Jewish research into hunger in the ghetto}

The Germans crammed half a million Jews into the Warsaw ghetto, an area less than 1000 acres. In 1941 Germans received $2613 \mathrm{kcal} /$ day, Poles 699 and Jews 184-less than 15\% of the minimum daily requirement. ${ }^{17}$ Death by starvation in the Ghetto had reached an appalling total of 50000 by 1941. In February 1942, 33 Jewish doctors in the Ghetto decided to make a study of the irremediable starvation. ${ }^{15}$ They studied children aged 6-12 years and adults aged 20-40 years, intending to remove the confounding factors of infancy, normal puberty and old age. They carried out many thousands of examinations and 3658 autopsies. Their work was hidden and published after the war and was one of the foundations of understanding the pathological aspects of starvation. ${ }^{18}$ Only eight of these doctors survived the war. The relevant research sites were visited and the study was presented by one of the group, providing stark contrast to the Nazi research.

\section{Courage of medical professionals}

Janusz Korczak was a paediatrician and principal of an orphanage in the Warsaw ghetto. Rather than escaping to the Aryan side of Warsaw, he chose to accompany his deported charges to the concentration camp and ultimate death. The scene outside the orphanage was later recalled by Berman. ${ }^{15} 19$ The group received a lecture on this subject and visited a monument dedicated to Dr Korczak.

Tadeusz Pankiewicz was a Christian pharmacist. The group visited the site of his pharmacy, Apteka Pod Orleo (The Pharmacy Under the Eagle), strategically positioned on the border of the ghetto in Krakow. A pharmacist in the group related how the site allowed him to smuggle Jews, food and medication in and out of the ghetto. Although he was not Jewish, he had risked death by his efforts. ${ }^{20}$
In the previous sections, supererogatory acts have been described that may initially seem of doubtful relevance to quotidian moral behaviour. However, they provide lessons in survival and functioning when faced with extreme situations and impossible choices. Similar dilemmas could be faced by military physicians and we discussed the pressure on physicians who stayed true to their humanity and vocation, remaining resolutely professional and compassionate.

\section{Inmate doctors}

Gisella Perl was a gynaecologist from Hungary. She was deported to the Auschwitz-Birkenau concentration camp in 1944 and was made to work as an inmate doctor in the infirmary, which was nothing more than an unconverted former horse stable. There was little in the way of treatment and often none at all. Perl describes how she tried her best to help the prisoners, despite the primitive conditions and without anaesthetics. She assisted at births and carried out abortions ${ }^{21}$ since being pregnant in the concentration camp was a death sentence. Her actions and her moral dilemmas regarding abortions to save the mothers were discussed in an AVP. ${ }^{22}$ These are well expressed by Meyerhoff '[She] risked death and eternal damnation... and came to be hailed on behalf of 'simple humanity' at the price of thousands of lives which might have been, but never were and never will be. [She]was right in being what she was by committing this enormous wrong.'

Aliza Baruch was deported as a girl to Auschwitz from Saloniki, Greece. She was ordered to be sterilised by Dr Mengele as a part of a brutal human experiment on sterilisations. The surgery was performed by a Jewish doctor under the watchful eye of a Polish doctor in the infamous medical Block 10. After the war, although she believed that she had been rendered infertile, she became pregnant. The Jewish doctor had pretended to sterilise her while the Polish doctor was distracted during an air raid. The Jewish doctor was later put to death. His actions were discussed in an $\mathrm{AVP}^{23}$

\section{Ceremonies}

Great importance was placed on military ceremonies performed by the participants at concentration camps and other places of mass slaughter, to honour the victims. The ceremonies were performed in full dress uniform. Eulogies and psalms were read.

Table 1 Data from questionnaires collected from participants in the 'Witnesses in Uniform' programme

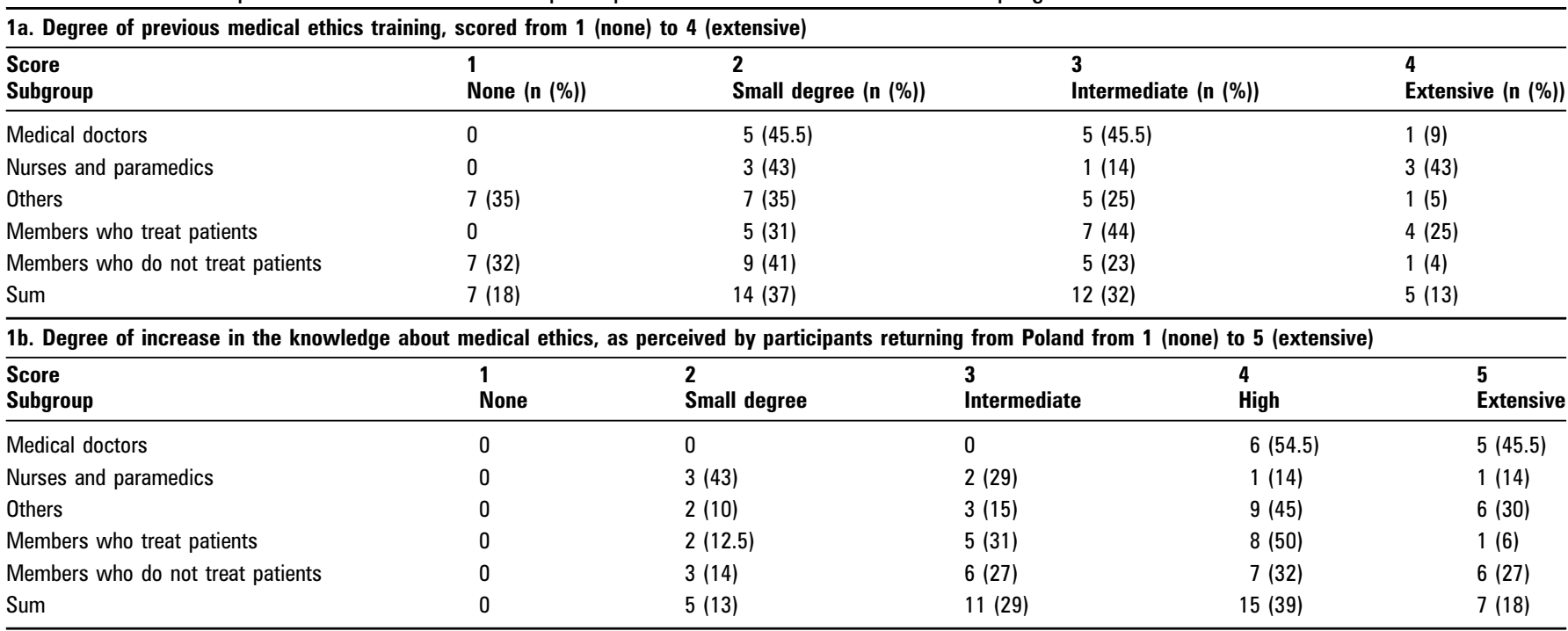


Kaddish, the traditional Jewish prayer for the dead, was recited and the Last Post was sounded. Two ceremonies were of special note. The first, on the bleak site of the Treblinka concentration camp, where 13 doctors read the names of 13 of the doctors among the hundreds who were killed at this camp. The names included that of Janusz Korczak and other doctors discussed during the programme. Another moving ceremony took place at the British military cemetery in Krakow. Standing among the graves the group was told how British Prisoners of War (POWs) did all in their power to stop Jewish POWS being separated from the rest of the troops by the Nazis. Wilson described how in one group of POWs, when the Jews were instructed to take three steps forward every single soldier in the unit took three steps forward. ${ }^{24}$ British troops showed morals and ethics not often seen in other armies.

The ceremonies illustrated military ethics, showing honour and respect, while visiting the British graves illustrated loyalty, duty and personal courage.

\section{SURVEY}

An anonymous questionnaire was mailed to all the participants a few months after returning. Questions included demographic and professional data, previous medical ethics training, previous knowledge about the Holocaust, and perceived value, importance and impact of the journey. The group consisted of largely experienced and qualified medical professionals, with an assumed previous basic knowledge and understanding of medically associated ethical dilemmas. The programme's aim was to stimulate study before, during and after the trip, and to increase awareness and promulgation of ethical issues within the Corps. The retrospective study was to gauge previous ethical training, as well as perceived value among the participants, as opposed to specific knowledge base or the development of cognitive/ behavioural skills. In the literature, surveys have been used as means of evaluating programmes in ethics. ${ }^{2}$ A similar survey, with similar questions, was used by the Brook Army Medical Center. ${ }^{25}$

Statistical analysis of the questionnaires was done using Fisher's exact test.

\section{RESULTS}

Thirty-eight of 49 participants (78\%) answered and returned the questionnaire. Professions of the participants were (n, \%): medical doctors (11, 29\%), medical organisation officers (7, $18 \%)$, nurses $(6,16 \%)$, administration staff $(5,13 \%)$, paramedic $(1,3 \%)$, psychologist $(1,3 \%)$ and others $(7,18 \%)$. Sixteen $(42 \%)$ of the participants had a job that included treating patients, and the remaining 22 (58\%) worked either in medical management and logistics or were reserve duty personnel with non-medical civilian professions. One participant was younger than 25 years, nine (24\%) were $25-30$ years old, 14 (37\%) were $30-40$ years old and $14(37 \%)$ were aged more than 40 years.

Participants had received various degrees of previous medical ethics training before the programme (see table 1a). When comparing subgroups, nurses and paramedics reported having been exposed to more medical ethical training than other subgroups, including doctors $(p=0.043)$. Members who treated patients reported a greater degree of previous training than those who did not treat patients $(\mathrm{p}=0.017)$.

The survey showed that members of the group that travelled to Poland thought that their knowledge about medical ethics had increased due to the programme (see table 1b). No statistical difference was found in the way that members felt their knowledge of medical ethics had increased in group members who treated patients compared with those that did not. A significant difference was found between the amount that different professional subgroups felt that their knowledge had been improved $(p=0.02)$ : doctors within the group felt that their knowledge had been increased to a greater degree than other subgroups.

All but one participant thought that 'Witnesses in Uniform' is a good programme to train military medical personnel in medical ethics.

\section{DISCUSSION}

Medical ethics, military medical ethics, as well as military ethics, should be an essential part of education programmes for military healthcare personnel, but remains neglected. It should be taught in the military since complex ethical dilemmas arise during routine work and combat. The IDF and its Medical Corps emphasise ethics in training soldiers and commanders, relying on global human systems and on the Jewish tradition.

'Witnesses in Uniform' takes officers on a journey to Holocaust sites. A special delegation commanded by the IDF Surgeon General has been a unique opportunity for officers of the Medical Corps to learn about special issues of medical ethics in an experiential 'out-of-classroom' way. Intense experiences and stories were discussed during the group's journey and their reflection on current issues. The dilemmas discussed included distributive justice medical research and many others already mentioned. Other complex topics that we discussed were medical treatment of injured terrorists, enemy personnel, and the interaction with innocent populations in military controlled areas. The outcome of these discussions were that participants were able to recognise unethical acts and knew what safeguards are in place to stop unethical behaviour, and why they are in place. They realise and recognise why safeguards failed in the past and may do so again in the future. The programme was very successful in achieving a deep sense of understanding of moral and ethical dilemmas, increased knowledge, and stimulated further interest in these ethical subjects. It has led to an obligation to spread the messages to other soldiers and officers.

Competing interests None.

Provenance and peer review Not commissioned; externally peer reviewed

\section{REFERENCES}

1. Boyd JW, Himmelstein DU, Lasser K, et al. U.S. medical students' knowledge about the military draft, the Geneva conventions, and military medical ethics. Int $J$ Health Serv 2007; 37:643-50.

2. Beam TE, Howe EG, eds. Military medical ethics. Falls Church, Virginia USA: Office of the Surgeon General, 2003.

3. Gross MI. Bioethics and Armed Conflict. Cambridge Massachusetts: MIT Press, 2006.

4. Reis S. Holocaust and medicine-a medical educational agenda. Isr Med Assoc J 2007;9:189-91.

5. Proctor RN. Racial Hygiene. Medicine Under the Nazis. Cambridge: Harvard University Press, 1988

6. WMA General Assembly. WMA regulation in times of Armed Conflicts. Tokyo: WMA General Assembly, 2004

7. Rosner F. Ethical dilemmas for physicians in time of war. Isr Med Assoc J 2010;12:133-4.

8. Howe EG. Teaching Military Medical Ethics at the Uniformed Services University of the Health Sciences. Virtual Mentor 2007:9:688-91.

9. Trunk I. Judenrat: The Jewish councils in eastern Europe under Nazi occupation. Lincoln: University of Nebraska Press, 1996.

10. Roland CG. An underground medical school in the Warsaw ghetto1941-2. Med Hist 1989;33:399-419.

11. "A time to heal". The story of the children's home in Otwock, Poland [internet]. Yad Vashem, the holocaust martyrs' and heroes' remembrance authority, digital exhibitions. http://www1.yadvashem.org/yv/en/exhibitions/otwock/intro.asp.

12. Coller BS. The physician-scientist, the state, and the oath: thoughts for our times J Clin Invest 2006;116:2567-70. 
13. Chelouche T. Medicine and the Holocaust-Lessons for present and future physicians. Med Law 2008;27:787-804.

14. Gordin MA. Historical origins of the Nuremberg code. In: Annas GJ, Grodin M, eds. The Nazi doctors and the Nuremberg code. Human rights in human experimentation. New York: Oxford University Press, 1992.

15. Gilbert M. The holocaust. The Jewish tragedy. London, UK: Harper Collins, 1986.

16. Lifton RJ. The Nazi Doctors. New York: Basic Books Inc, 1986.

17. Sterling EJ, ed. Life in the Ghettos during the holocaust. Syracuse New York, USA: Syracuse University Press, 2005.

18. Winick M, ed. Hunger disease. Studies by the Jewish physicians in the Warsaw ghetto. New York and Chichester: John Wiley \& Sons 1979

19. Adolf Avraham Berman testimony, Adolf Eichmann trial session 26. May 3, 1961. http://adolfeichmanntrial.com/adolf-eichmann-trial-sessions/trial-of-adolf-eichmann- sessions-1-through-30-defense-submissions, and at http://www.nizkor.org/hweb/ people/e/eichmann-adolf/transcripts/Sessions/index-01.html.

20. Gilbert M. Holocaust journey. Travelling in search of the past. London: Phoenix Weidenfield \& Nicolson, 1997.

21. Perl G. I was a doctor in Auschwitz. New York, USA: Arno Press, 1979.

22. Out of the Ashes [film]. Showtime. Released 13 April 2003.

23. "May your memory be love"-The story of Ovadia Baruch [film]. Witnesses and Education Project, the international school for holocaust studies and the multimedia center of the Hebrew university of Jerusalem, Israel, 2008.

24. Wilson AN. After the Victorians. London: Hutchinson, 2005.

25. Kemp KR, Thompson JC, Ong B, et al. Ethics training for military trainees: the Brooke Army Medical Center experience. Mil Med 2008;173:968-74. 